\title{
Constructing Papal Identity during the Great Western Schism (1378-1417): Pierre Ameil and Papal Funerals ${ }^{1}$
}

\begin{abstract}
This essay argues that liturgists responded to the Great Western Schism (1378-1417), with liturgical rubrics. During this period, authors were essentially motivated with the recovery of ecclesiastical unity. I will analyze how Pierre Ameil, a contemporary of the Schism and the author of a ceremonial book or ordo attempted to reconstruct unity by developing a new rubric centered on the rituals surrounding the pope's death. By keeping the papal body one, both natural and institutional, Ameil responded to the College of Cardinals whom he knew was responsible for the initiation of the crisis. Contrary to current historiography that sees liturgists building institutional continuity during the Vacant See on the College of Cardinals, the essay proposes that Ameil built continuity on the embalmed papal corpse presenting it as both natural and institutional, at once finite and eternal.
\end{abstract}

\section{Introduction}

How did medieval secular or religious authorities preserve the continuity of their particular system when the personal representative of that system died? In The King's Two Bodies, Ernst Kantorowicz advances the notion of the dual representation of the king's body as both natural and political. When a king died, only his natural body died, while the king's majesty (dignitas) survived in the monarchical institution. During the Middle Ages, the presence of funeral effigies in the religious rituals of death brought home the "political theology" of secular monarchies. They presented the king's dignitas. ${ }^{2}$

Developing further this basic paradigm, Agostino Paravacini Bagliani suggested that ecclesiastical authors also framed institutional continuity at the death of a pope; the natural body of a pope may die but the institutional body of the papacy survived in the College of Cardinals. ${ }^{3}$ Paravacini Bagliani states, "By 1378 [...] the cardinals were now the undisputed

\footnotetext{
${ }^{1}$ This study draws from several previous works, mostly: Rollo-Koster 2008; Rollo-Koster 2009; Rollo-Koster 2015; Rollo-Koster 2016. My thanks to the editors of the volume; the anonymous reader of my draft; URI, for granting me an academic year sabbatical in 2017-18; and the Marie Curie EURIAS fellowship that allowed me a year of academic focus at the Swedish Collegium for Advanced Studies.

${ }^{2}$ Kantorowicz 1957.

${ }^{3}$ Paravicini Bagliani 2000.
} 
guarantors of the transfer of the potestas papae. Indeed, the cardinals were the church during the limited period of the papal vacancy". 4

When, in 2014 he revisited the thesis of The Pope's Body for the twentieth anniversary of its first publication, Paravicini Bagliani built from his earlier findings underscoring the role played by Innocent III and Boniface VIII, but also Honorius III (1216-1227) in the development of a simultaneously sacred and physiological approach to the pope's body. ${ }^{5}$ A paradox stood at the heart of the question. The medieval church attempted to prolong the life of its pontiff and extol the perfection of his body, while emphasizing his mortality. Still, the uniqueness of Paravicini Bagliani's historical intuition is to have identified how the body of the pope offers a field of study for analysing mechanisms of powers. "[The body] offers a perspective on the anatomy of the body of power, along great cultural and ideological itineraries such as the perfect body or the body of the sovereign as 'support' of order". ${ }^{6}$ Kantorowicz's basic insight regarding the king's secular body pointed a way forward to consider the papacy as grounded in the pope's own corporeity, an essential element foundational to ecclesiastical order and hierarchy. ${ }^{7}$

Traditionally, the historiography of the Vacant See suggests that medieval authors framed ecclesial continuity around the College of Cardinals. In funeral rites, this crucial shift from the personal to the collegial was made clear when, after a quick exposition the remains of a pope were buried early into the novena, leaving visible only his symbolic presence, an empty catafalque. It is this castrum doloris that maintained the simulacrum of the pope's institutional presence while cardinals ruled the church sede vacante. While this conception remained valid for the later Middle Ages and the early modern period it is left to identify what happened with Pierre Ameil when he drafted his ceremonial during the Great Western Schism.

This essay, focusing on Pierre Ameil, a contemporary of the Schism and the author of a ceremonial book or ordo, allows us to examine how a liturgist, aware of the role the College of Cardinals played in the initiation of the crisis, and of its encroachment on papal prerogatives, responded to its political actions. I will suggest that he employed the tools of his trade, liturgical rubrics. By being first in developing a new rubric on papal death, he constructed ecclesiastical continuity on a single papal body, both natural and institutional. In contrast to the historiography previously cited, which overlooks his work, Ameil refused to build institutional continuity on the College of Cardinals, but rather emphasized the embalmed papal corpse, presenting it as both natural, finite, institutional, and eternal.

I will argue that while monarchies developed the practice of proceeding the king's body in effigy during funerals - to soften the political transition, Ameil did not. He kept the physical body of the embalmed papal corpse as living representation of the Church, naturally metamorphosing the dead man into the institutional body of the Church. Recording and scripting the papal funeral Ameil repositioned the papal corpse. The dead pope did not need statuary, or inorganic representation to signify its everlasting institutional presence. It was in one body as much living and transient, as it was dead and permanent.

\footnotetext{
${ }^{4}$ Paravicini Bagliani 2000, 155.

${ }^{5}$ Paravicini Bagliani 2014, 17.

${ }^{6}$ Paravicini Bagliani 2014, 31.

${ }^{7}$ Paravicini Bagliani 2014, 31.
} 


\section{Schism}

The Great Western Schism (1378-1417) is often described as one of three calamities that plagued the fourteenth century, along with the Black Death and the Hundred Years War. The Schism imploded western Christian unity, literally dividing Western Europe into two camps, each obeying their respective popes. ${ }^{8}$ Upon his election in December 1370 , Pope Gregory XI emphasized his wish to return the papacy from Avignon, where it had been since 1309, to Rome. It took him a few years to set his plan into motion but eventually he left, arriving in Rome on 17 January 1377. Gregory died a few months later, on 27 March 1378, without a doubt satisfied that he had returned the papacy to its traditional home. Following canon law, on the night of 7 April 1378 the sixteen cardinals present in Rome entered into conclave and on the following day, despite internal divisions between Limousins and northern French, and a boisterous Roman crowd chanting at the conclave's windows, elevated Bartolomeo Prignano, archbishop of Bari, as Pope Urban VI (+1389).

Urban managed early on to offend many of his cardinals. By June 1378, unhappy French cardinals started leaving Rome for Anagni, and on 9 August 1378 they posted a Declaratio on the gates of the city's cathedral, denouncing Urban's election as fraudulent because it had taken place under duress and violence. The cardinals justified their action using the Corpus Iuris Civilis, Dig. 4.2.1: “[ULPIANUS] Ait praetor: 'Quod metus causa gestum erit, ratum non habebo" (what is done through fear I will not uphold) that addressed compulsion and fear, and which allowed fear as a ground for the invalidity of official acts even if and when performed publically. They asserted the illegality of an election in which the Roman mob had subjected them to a "fear of the kind that can conquer even a steadfast man" (metus qui potest cadere in constantem virum). Settling at the court of Onorato Caetani in Fondi, in the Kingdom of Naples, thirteen rebellious cardinals denounced Urban's legitimacy, and elected Robert of Geneva as Pope Clement VII (1378-1394). ${ }^{9}$ Urban VI never recognized Geneva, and the Schism was consummated. European countries aligned themselves according to their preferences and interests and the Schism lasted until cardinals--and politicians--decided on unity. After a failed conciliar attempt at Pisa in 1409 that muddied the situation even more by bringing into the fray a third pope, the Council of Constance, held between 1414 and 1417, effectively ended the crisis by accepting the resignation of the Pisan claimant John XXIII, and of the Roman claimant Gregory XII, and then deposing both, and the Avignonese claimant Benedict XIII. It elected Martin V as unique pope of western Christendom in November 1417.

Modern students of papal history agree that the French cardinals were largely instrumental at its inception. ${ }^{10}$ It is obvious that the cardinals regretted their choice of Urban soon after electing him, especially when he turned imperious, reproving and erratic. Cardinals saw the pope at the head of the Church and themselves as its trunk and limbs. They wanted participation in decision-making and their own share of the Church's revenue. They also resented that

\footnotetext{
${ }^{8}$ For a quick survey of the Schism see, Rollo-Koster 2015, 239-286; for a more detailed analysis see, Rollo-Koster and Izbicki 2009.

${ }^{9}$ On the initiation of the Schism see Rollo-Koster 2008.

${ }^{10}$ See for example, Weiß 2009. In his introduction to the $39^{\text {th }}$ Cahiers de Fanjeaux dedicated to the Schism in the French Midi Jean-Louis Biget leaves no doubt by also pointing his finger in the direction of the French cardinals, who, according to him, used violence as a pretext to renege their original choice of Urban VI; Biget 2004.
} 
the pope not allotted them portions of all taxes (like the annates). The pope and his cardinals also clashed over competitive visions of personal observance of apostolic life (vita apostoli$c a$ ) appropriate with their positions. The pope was intent on fighting simony and other abuses and some cardinals no doubt resented Urban's reform agenda and his pressing summons to religious discipline and austerity. What transpires is that the Schism was tightly bound to the relationship between the pope and his cardinals; and as such these rapports reflected on liturgy.

\section{Ceremonial books and liturgy}

Ceremonial books or ordines were in use at the curia since the early Middle Ages with, for example, the Ordines Romani centering on the liturgy of the great Roman churches. As the papal court grew in size and organization, so did its liturgy. Ordines attempted to guide and order the curia's liturgical life. Over time, they grew to deal with the vacant see and papal election, coronation and consecration, calendrical liturgy from Christmas to Pentecost, masses, sermons, anniversary celebrations, consistories, councils, imperial and royal coronations, canonizations, cardinals' elevation, ecclesiastical transfers, and the charges of nuncios and legates, etc. ${ }^{11}$ Ceremonials accrued their information but rarely innovated or varied widely from one text to the next. ${ }^{12}$

Jean Mabillon (1632-1707), the earliest compiler of Ordines Romani itemized fifteen of them, ending his compilation in the late Middle Ages. Variations and precisions to Mabillon's schedule have been added over time by authors like Michel Andrieu, Marc Dykmans, or Bernhard Schimmelpfennig. ${ }^{13}$ There is no doubt when perusing these books that celebrants and their assistants were in fact the ordines' prime audience. This means that ane moment or another, most officers of the papal court played a role according to these ceremonials, from the pope, to the camerlengo, cardinals, bishops and priest, confessors, deacons, chaplains, cantors, treasurers, sacristans, penitentiaries, down the hierarchical ladder to the physicians, barbers, messengers, and almoners of the pope. In the words of Pierre Ameil, who will be analyzed below, ceremonials instructed those who needed to follow accurately forms found in older ceremonials. $^{14}$

This essay, focused on Ameil's liturgy, will engage medieval sensory, especially visual and olfactory perception. Venturing into a discussion of how medieval people saw and smelled may help understand what a liturgist intended to communicate. In general terms, as Dallas Denery states, by the later Middle Ages "people had come to think about themselves primarily in visual terms, in terms of a somewhat amorphous distinction between what appears and what exists". ${ }^{15}$ This vague distinction between appearance and existence led people to conceive themselves in terms of how an audience saw them. What was a liturgist's visual frame of reference when he wrote his ordo? In a certain sense, what a liturgist saw and what he expected his audience to see found its way in descriptions of liturgical procedures.

\footnotetext{
${ }^{11}$ See for example the ceremonial for the early fourteenth century in Dykmans 1981. For a general discussion of the historiography and evolution of ceremonial books see Rollo-Koster 2008, 44-48.

${ }^{12}$ Ceremonials differed from other liturgical texts because they only offer incipits. For a recent survey see, Palazzo 1998.

${ }^{13}$ See, Mabillon 1724; Andrieu 1931-1961; and 1938-1941; Dykmans 1983 and 1985 and b; Schimmelpfennig, 1973.

${ }^{14}$ The text reads, "que debent dari iuxta formam que est in Politico et in Pontificali Romano". Dykmans 1985, 217.

${ }^{15}$ Denery 2005, 7.
} 
In Herbert L. Kessler's formulation, seeing in the Middle Ages led to perceiving. For this author, the physical act of looking at various forms of medieval media led the onlooker toward the spiritual experience of sensing and perceiving what was represented. ${ }^{16}$ Thus, rather than conceptualizing seeing as a physical reality, the sense became perception, and as such, attached to the entire cultural apparatus linked to what one perceives depending on who, when and where, etc., one is situated. In the case of Pierre Ameil it could be argued that what he saw was defined by who he was, where, and when. He made liturgy his, prescriptive and traditional indeed but still filtered through the personal visual prism of a man of the Schism.

If sight and hearing remained the preferred senses of the Middle Ages, smell still kept a prominent place in medieval sensorial hierarchy, and in Ameil's script. After resisting the attraction of fragrance because it evoked too easily pagan practices, Christianity embraced it for its distinctive qualities. Enshrined in 2 Corinthians $2: 14-16,{ }^{17}$ smell became a sign of Christian adoration, and prayers, the ephemeral and memorial link between the profane and the sacred. Smell vanishes quickly but a whiff can propel instantly into memories, and feelings. Smell also transforms any profane location into sanctified, ceremonial space.

Discussing the growing importance of smell in early medieval liturgy, Susan Harvey sees the emergence of "a lavishly olfactory piety" in the early Middle Ages, that she also labels "a piety of fragrance", adding that Christians knew of the "sweet fragrance of God". ${ }^{18}$ Constance Classen refers to medieval Christianity as "olfactory theology". ${ }^{19}$

Incense and balsam found their place in Christian liturgy. ${ }^{20}$ Incense became the favoured medium to link the profane to the divine. Its use became liturgically mandatory during funerals. And balsam, mixed with olive oil transformed into the holy chrism of consecration, became the symbol of the Holy Ghost's 'presence'. This liturgy of smell propagated the idea that Christianity and holiness were fragrant, and contrarily sin and evil stank. As we will see, Ameil did not hesitate to use fragrance profusely in his funerary liturgy, and thereby heightened the sacredness of the papal body.

This essay will suggest that the Great Western Schism directed Pierre Ameil in the penning of his ordo's rubrics. He was aware of the role the College of Cardinals played in the initiation of the crisis. He responded by augmenting papal ceremonial books with a new section focused on the pope's death. And there, he minimized the role of cardinals during the moment to construct ecclesiastical continuity on the pope, on a single papal body, both natural and institutional, and eventually bonding the pope with Christ.

\footnotetext{
${ }^{16}$ Kessler 2004. The idea is somewhat pushed further by Sand 2014, 4, who while discussing reading processes describes "a recursive loop between subject and object--the viewer sees herself seeing and thereby attains a heightened awareness of her own visibility and her own vision".

17 "But thanks be to God, who always leads us as captives in Christ's triumphal procession and uses us to spread the aroma of the knowledge of him everywhere. For we are to God the pleasing aroma of Christ among those who are being saved and those who are perishing. To the one we are an aroma that brings death; to the other, an aroma that brings life. And who is equal to such a task?"

${ }^{18}$ See Harvey 2006, 2, 91, 48.

${ }^{19}$ Classen 1998, 53.

${ }^{20}$ See, for a thorough discussion, Albert 1990; Benoit 2012; Classen 1998; Classen 2002; Harvey 2006; Jørgensen 2013; Le Guérer 1993; Reinarz 2014; Roch 2009; Woolgar 2006.
} 


\section{Pierre Ameil and his Ordo}

Pierre Ameil was born in the French Midi, received a bachelor degree in theology, and eventually moved to the papal court in Avignon at the time of Urban V. There he served as an associate of the papal sacristan, who also was papal librarian and confessor. Ameil was appointed papal librarian and bishop of Senigallia under Gregory XI, and finally named papal confessor. A direct witness of the election of 1378 he remained papal confessor and steadfast in his allegiance to Pope Urban for the rest of his life. Around 1386 Urban VI elevated him to the patriarchate of Grado. Boniface IX named him referendary (a Chancery' office), and he represented the pope at Avignon in 1394 to prevent the election of a new pope at the death of Clement VII. Once his attempt failed he returned to Rome where he remained until his death, sometime before May 1401. He left several literary works of importance: a 1375 inventory of the papal library, a rhymed chronicle of the return of Gregory XI to Rome in 1377; and finally, his ceremonial. ${ }^{21}$

I am in no way suggesting that Ameil in his liturgical approach offered radical solutions for the Vacant See that would have been inspired by his experience of the Schism. He kept in place the traditional markers of ecclesiastical continuity, the camerlengo, and cardinals, who were in charge of affairs while the seat remained vacant. But his concern for the crisis and his pope (Urban VI) led him to present and communicate his vision of unity though his liturgical rubrics. By being the first liturgical writer to actually focus on the pope's dead body, Ameil combined both office and person in his iconization or objectification of the papal corpse. When Ameil looked at the embalmed papal corpse, he saw a transfiguration of a formerly living creature framed by his understanding of Corpus Christi.

Pierre Ameil like his contemporary François de Conzié, penned a ceremonial describing the pope's death and transfer of power. Both authors wrote during the Great Schism: François de Conzié, during the 1390s, and Pierre Ameil during roughly the same period (c.1370c.1400). ${ }^{22}$ Interestingly enough, both authors constructed funeral rites that reinforced the role of parties other than the cardinals. De Conzié did not focus on the pope's body but rather emphasized the Camerlengo's administrative control of the sede vacante, while Ameil constructed papal continuity on a single papal body, at once natural and institutional. Ameil objectified the pope's body as a means to evocate his institutional continuity.

It is important here to underscore that Pierre Ameil's ordo was the first to focus particularly on the corpse of the deceased pope, and this focus allowed him to find unity. ${ }^{23}$ Ameil prescribed behaviour during the pope's final agony, embalming, exposition, and transport to the funerary chapel. Ameil ends his ordo with a rubric concerning the conclave and a few historical notes on the deaths of popes Gregory XI and Urban VI. ${ }^{24}$ I would emphasize that Ameil's

\footnotetext{
${ }^{21}$ Dykmans 1984a, 13-20.

${ }^{22}$ For de Conzié's ceremonial, see Dykmans 1983. Dykmans 1983, vol. 1, 73, suggests the date of 1390 for de Conzié's composition, thus before the conclave that elected Benedict XIII; as for Ameil, his work cannot be dated exactly to a single year, but belongs rather to the last 30 or so years of his life (c.1370-c.1401); see Dykmans 1985, 25-36, 66.

${ }^{23}$ It is of note that recently Peter D. Clarke has highlighted regulations emanating from the fourteenth-century Penitentiary, including a description of the role that penitentiaries played during the papal funeral. These documents found in Washington D.C at the Catholic University of America Library, manuscript 185, describe and prescribe behavior but cannot be considered liturgical ordines per se. They were a series of statutes concerning penitentiaries and not full itemization of the liturgical calendar. See, Clarke 2009. Göller 1907, 144-146 addresses the same documents.

${ }^{24}$ Dykmans 1985, 216-233.
} 
personal experience with the Schism informs the concern he showed for the remains of the deceased pope as a strategy to both assert the pope's legitimacy, and uniqueness. By exalting the papal body, Ameil was legitimating this pope, the devotional center of a ritual of political and liturgical continuity, and not some other pretender.

In his Regimen custodiae corporum mortuorum the famous medieval surgeon Gui de Chauliac, explains two types of embalming: a "clean" practice for the cold season, that he considered a better fit for bodies that were skinny and dry, and a more invasive one, better fitting fat bodies. ${ }^{25}$ Ameil's papal embalming did not follow de Chauliac to the letter, but approximated his methods. The preparation, washing and dressing of the corpse took place in the secret/private chamber of the pope. ${ }^{26}$ As the penitentiaries recited the Office of the Dead, the seven penitential psalms, and other prayers, brothers of the Bull (seal) Office or of the papal almshouse washed the pope's body with warm scented water, and a barber shaved his head and beard. ${ }^{27}$ The brothers and an apothecary filled his anus, mouth, ears, and nose with cotton, oakum or myrrh, incense, or aloe if available, then they once again rubbed the body with a good white wine heated with smelling herbs, and with a good Garnache wine provided by a chamberlain or butler. The next step included stuffing the throat with herbs, spices, and cotton, his nostrils with nutmeg, rubbing the body vigorously, including the hands, and anointing it for one last time with a good balsam provided by the chamberlains. ${ }^{28}$

Before going any further into the discussion, it is worthwhile to pause and reflect on how Ameil's papal corpse could have smelled for its 'audience'. According to Jonathan Reinarz, "scents signified individual and group identity in a morally constructed universe, where the good smelled pleasant and their opposites reeked". ${ }^{29}$ The papal body enveloped in a cacophony of sweet fragrances - and certainly also putrefaction - must have smelled unique. With the exception of royalty, no other corpse could have smelled like him. The sweetness of balsam, wines, incense, myrrh brought back emanations of holiness, sainthood, and religious ceremonials. All medieval folk knew that there was an 'odor of sanctity' and that sweet-smelling corpses "demonstrated the power of God to place mortals outside the seemingly universal decay of death". ${ }^{30}$ But it can be assumed that behind sweetness, the stench of death lingered, reminding witnesses that the smell of this special corpse also symbolized its caducity. The pope literally smelled like who he was: a symbol of corruptible humanity (the stench of his body) and institutional immortality (the sweet fragrance of his embalming).

Still, it is remarkable that Ameil dresses the papal body in a profusion of fragrances that may have been intended to utterly dissimulate the scent of his physical corruption. If he could hide the stench of death with his 'liturgical' fragrances, then he could suggest sensually the sweet fragrance of institutional immortality. As such he reinforced his vision of a unified papal body, still human but at the threshold of immortality. The papal corpse's 'mixed' fra-

\footnotetext{
${ }^{25}$ See La Grande chirurgie de maistre Guy de Chauliac...traduite nouvellement en François...par Maistre Simon Mingelousaulx... première édition [suivi de l'Antidotaire] 1672, 522-524. For a discussion of embalming, see RolloKoster 2016.

${ }^{26}$ Dykmans 1985, 220.

${ }^{27}$ Dykmans 1985, 218.

${ }^{28}$ Dykmans 1985, 219.

${ }^{29}$ Reinarz 2014, 19.

${ }^{30}$ Classen 2002, 53.
} 
grance symbolized its unity: the physical/mortal -maybe barely perceptible, was enveloped in the fragrance of institutional immortality.

Once prepared, penitentiaries dressed the body with trousers, shirt, hose and a tunic. They arranged the corpse 'as if sitting' and covered him in his red papal garments that included first his white sandals, belt and cincture, fanon, stole, short tunic, maniple, dalmatic, gloves, chasuble, and a pallium which following custom hailed from the body of St. Peter. ${ }^{31}$ They folded the fanon on his head and around his shoulders as if he were going to officiate and they put on his head his white biretta and mitre without pearls or gold. ${ }^{32}$ The pope was laid on a bier over a mattress covered with red silk and gold cloth, his head and feet resting on pillows covered with silk and gold. ${ }^{33}$ The next step was to move the prepared and readied corpse out of the papal chamber to the chapel, and eventually bury him.

For a late medieval author like Ameil, the dead pope stood as a liminal representation, not alive but yet not dead--as noted above, the corpse was dressed "as if he were to officiate",-slowly transitioning into and integrating, during the novena and its ritual, the long list of Peter's successors. Ameil, speaking to a clerical audience, framed the embalmed pope as a symbolic object rather than a corpse. This allowed him to offer his pope enduring dignitas. Even as dead, the pope remained for this agent of papal culture the essence of the institution. Ameil was resisting the College of Cardinals with the means at his disposal: ritual. For him the College was a rival center of power, which attempted to separate the institutional dignitas of the pontiff from the dead man's body.

Nowhere is Ameil's resistance to seeing the papal office and body separated more visible than in his silence about one of the most crucial moments of the Vacant See: the destruction of the papal bull's matrix that ended the legitimate rule of a pope. The ceremony was an important one and Ameil's contemporary, François de Conzié, details its various steps. The vice-chancellor oversaw the destruction of the papal seal (or bull from the Latin bulla). The seal communicated clearly the duality of the papacy: immortal and mortal. The seal's matrix showed the coat-of-arms of the man-pope while the counter-seal's matrix showed the images of Peter and Paul, who symbolized the perpetuity of the ecclesiastical institution. The vicechancellor gathered the matrices from the bullatores and wrapped them in a thick cloth, which he sealed with his signet to further prevent publication of any official documents under the former pope's name. After this, the Prior of the Cardinal-Bishops convoked the cardinals in the pope's dressing room next to the pope's bedroom, as they witnessed the vicechancellor's exhibition and destruction (with a hammer) of the pope's seal. The cardinals sat on bare benches according to order of precedence, while the camerlengo, treasurer, and clerks of the chamber stood behind them. Once the pope's seal was obliterated, the apostolic matrix was handed for safekeeping to the camerlengo until the election. If the camerlengo was not available, the vice-chancellor kept the matrix after the bishops' prior sealed it. ${ }^{34}$

It is impossible to know why Ameil brushed aside a key moment of the vacant see that marked with no equivocation the end of a pope's rule. What is remarkable is that Ameil's

\footnotetext{
${ }^{31}$ On the consecration of the pallium in the tomb of St. Peter or at the altar of St. Peter see de Blaauw 1994, vol. 2, 710 712; Schoenig 2016.

${ }^{32}$ Dykmans 1985, 219.

${ }^{33}$ Dykmans 1985, 219-220.

${ }^{34}$ See Dykmans 1983, vol. 1, 265.
} 
rubrics up to that point had followed protocol, itemizing material covered by de Conzié. While the Papal Agony rubric of both authors ran similar entries, touching on the cardinals' visit, last sacraments, profession of faith, papal exhortation to the future electors, and indulgence, Ameil remained closer to the man-pope, reminding prelates to always be available to him, and hold a simple cross to his face for him to see and kiss "in memory of the Passion". 35 Discrepancies between the two authors get exacerbated in the next rubrics describing the aftermath of the pope's death. De Conzié exalts his responsibility right away, itemizing the camerlengo's actions in overseeing the preparation of the body, safeguarding papal possessions, destruction of seals, cardinals' preparation of the funeral and conclave, guard of the conclave, novena and actual funerals. ${ }^{36}$ Meanwhile, Ameil jumps from the securing of the pope's personal goods, to his embalming, exposition of the body, transport to the chapel, and inventory of goods present in his chamber, the pope's funeral (novena, mourning clothes, etc.) leading to the preparation of the location for the next election, the conclave. ${ }^{37}$ Ameil never deals with the strike of the hammer that symbolically separated man from office.

\section{Making sense of Ameil}

Agostino Paravicini Bagliani asks why the church created papal funerary rituals? He suggests, "the history of the pope's death has in fact appeared to be sustained by a common element: the conscious will to distinguish between the pope's physical person and the pontifical office". ${ }^{38}$ Thus funerary rites were grounded in the presentation of the pope's humanity (and thus mortality) during the funeral, to reassure that even though the man/pope died, his office, the institution, survived. This papal humanity explains why sometimes the body of the dead pope was humiliated, left unattended or stripped of his clothes. Here, I would argue that Ameil, by emphasizing the papal body with its embalming, and refusing to face the destruction of the papal matrices, blended the pope's humanity with his institutional perennity. Ameil saw the papal corpse as an imago, that took christological qualities. ${ }^{39}$

Ameils' depiction of the care attached to the dead pope emphasized embalming. The method largely meant filling cavities with "aromatic plants and spices" and "good balsam" as the body was rubbed with "good wine". The smell of putrefaction was also the smell of death and altering that smell implied altering death. ${ }^{40}$ Of course, rubbing, and filling a body with balsam carried enormous Christian implications. The anointing of Jesus by Mary Magdalene found in the four Gospels (Matthew 26:6-13; Mark 14:3-9; Luke 7:36-50; and John 12:1-8) held Christological significance. Matthew quotes Jesus saying "When she poured this perfume on my body, she did it to prepare me for burial". Thus, unction found significance in Christian liturgy and practices. ${ }^{41}$ Its use on the pope's body also found meaning. For Ameil, it altered the pope's body into Christ's body. In life, the pope's body represented his duality,

\footnotetext{
35 “Ad memoriam reducendo passionem Christi”. Dykmans 1985, 218.

${ }^{36}$ Dykmans 1983, vol. 1, 262-276.

${ }^{37}$ Dykmans 1985, 218-232.

${ }^{38}$ Paravicini Bagliani 2000, 161.

39 "Imago designates the image and then a representation, a portrait, a ghost (in poetic language), appearance (in oppos ition to reality);" Walter 2013.

${ }^{40}$ English does not offer the association that the French embaumer implies, that is embalming but also smelling good.

${ }^{41}$ Truitt 2009, 730-736, for a discussion of the meaning of balsam in Christianity.
} 
papal and institutional. In death, embalming offered the temporary fiction of eternal life. Anointed and embalmed, Christ and the pope maintained their fragrance, thence unity. As Jonathan Reinarz suggests smell is impregnation. "Fragrance announced phenomena that could not be seen, heard, or touched but that were still tangibly sensed. Compared with the other senses, smell also possessed a unique mobility, crossing boundaries that were otherwise difficult to breach, including that between heaven and earth". ${ }^{2}$

Evidence for this symbolic association between embalming spices and life-after-death may be found elsewhere in medieval literature. Returning to the death of Hector in John Lydgate's Middle English Troy Book (c. 1412-1420), Elly Truitt argues that balm was conceived in the Middle Ages as a miraculous potion that could preserve bodies and maintain the fiction of life. She notes that balm's ability to "halt corruption was noted and amplified", after the twelfth century citing well-respected physicians like Hildegard of Bingen. ${ }^{43}$ Thus balm with heat and moisture counteracted the effect of death and decay, constructed since Aristotle as "internal coldness and external heat". ${ }^{4}$

Christological markers can also be recognized in behaviors surrounding the papal corpse. I would suggest that Ameil treated the papal body as an object of memory, which in turn facilitated the association between body and object. This assimilation has been well researched with, for example, the cult of saints. Reviewing the historiography of the cult of relics Guy Marchal has recently highlighted their physical reality, their "real presence" to use Peter Dizenbalcher's terminology. ${ }^{45}$ As Marchal states, "The saint was concretely present in the relics", adding further "the material apparition of the saint was visible and emotionally palpable. The saint was personified through the anthropomorphic reliquary. ... the visualization of the saint was reached more rapidly in the image". ${ }^{46}$ It is also evident that saints were identified through their "smell of sanctity". ${ }^{47}$ It is imaginable that a society used to see the dead's presence as a tangible phenomenon could broaden the process to bones and flesh. But more importantly for the present purpose, Marchal explains how in the Middle Ages the act of looking - and I would like to add smelling - at something created a physical rapport between observer and object, "as if matter or energy flew from one to the other". ${ }^{48}$ Here I am suggesting that Ameil saw the institution in the papal body, and he saw it in Christological terms.

The process of seeing was actually reinforced during pious contemplation, when gazing at became a real visual (and, according to the emission theory, tactile) encounter with the saint, which R. W. Scribner has labeled "sacramental contemplation" or "sacramental gaze". ${ }^{99}$ With the 1215 officialization of Transubstantiation "the ecclesiastical doctrine of the Eucharist ... authenticated and intensified the perception of the cult's image. If God was present and visible in a pithy chunk of bread, how much more was the saint in the image". ${ }^{50}$ It is quite possi-

\footnotetext{
${ }^{42}$ Reinarz 2014, 19.

${ }^{43}$ Truitt 2009, 720.

${ }^{44}$ Truitt 2009, 728.

${ }^{45}$ See, Marchal, Rivière 1995; Dinzelbacher 1990; Thun $\varnothing 2002$.

${ }^{46}$ Marchal, Rivière 1995, 1139.

${ }^{47}$ See Albert 1990.

${ }^{48}$ Marchal, Rivière 1995, 1140.

${ }^{49}$ Scribner 1990, 9-20.

${ }^{50}$ Marchal, Rivière 1995, 1140.
} 
ble that for authors like Ameil, the pope's physical reality, his corpus ecclesie was subsumed into a higher corporeality; the papal corpse was for Ameil Corpus Christi. ${ }^{51}$

I would suggest that Ameil evoked and hinted at visual clues and scents, that led the public and audience of the funeral into seeing the physical body of the dead pope as the Corpus Christi of Eucharistic celebrations and processions. ${ }^{52}$ He presented images that formed his visual understanding of the papacy, physical and institutional. His construction reflected contemporary perceptions that intertwined images, and scents, maybe without really thinking about theological consequences. Recounting the passing of the funeral procession that returned the body of Henry V of England from France, a chronicler states "The coverlet of this bed was of scarlet silk embroidered with gold, and besides this in passing through the large towns there was carried aloft over the chariot a rich canopy of silk, like what is usually borne above the holy Sacrament". 53

In her study of Corpus Christi: The Eucharist in Late Medieval Culture, Miri Rubin emphasizes the visual experience of seeing the Eucharist. She suggests,

But the essence of the rite lay in seeing the host, and so candles were part of any scheme of veneration; bearing warmth and illumination into the dark chancels of medieval European churches, they were essential at the moment when the holiest appeared. Lighting was provided for illumination as long as consecrated hosts were kept in the church, as well as for the duration of the mass, and additional lights were required during the elevation. In the late twelfth century Lothar of Segni recommended two candlesticks at the corners of the altar with a taper and a cross between them, and two additional lights to be lit before the altar during the elevation. ${ }^{54}$

During the papal funeral, the presentation of the pope's body suggested a visualization of the Eucharist. Both were elevated on platforms and both were surrounded by lights. ${ }^{55}$ Both were fragrant, surrounded by the waft of incense. Ameil emphasizes the specific illumination of the corpse. Torches lit the papal corpse and its catafalque at all time, during its lay in state, and transport. In such ways, Ameil articulated his understanding of what the pope's body meant to him. ${ }^{56}$ And, it is remarkable that De Conzié who insists on his role of camerlengo during the Sede Vacante remains silent on the placement of lights during the papal funerary liturgy,

\footnotetext{
${ }^{51}$ Ameil's formulation fits Hans Belting's discussion of iconic portrait and the symbolic activities surrounding them. In the present case the image being the corpse. (see Belting 1995). But more so, Ameil's script reflected contemporary mentalities highlighted by Belting's student, Dominic Olariu, who sees in funerary practices of the late middle ages a revalorization of the dead body rendered lifelike with the common practice of thanatopraxy (the covering of the face and body with a wax encasing that offered the fiction of life). See Olariu 2014.

${ }^{52}$ See, Rubin 1991. Izbicki 2015, has recently updated the historiography.

${ }^{53}$ de Wavrin et al., 1887, 389.

${ }^{54}$ Rubin 1991, 60.

${ }^{55}$ One can note that the style of flamboyant funerals was in vogue in the late Middle Ages, see Chiffoleau 1980. It would be interesting to follow the development of this funeral style in parallel with Eucharistic devotion. There is no doubt that testators in the Comtat Venaissin associated lights with the body of Christ; Chiffoleau cites a testament where the author bequeathed a gift "to the taper that accompanies the body of Christ when it iterates in the city during the procession;" ibid., 362.

${ }^{56}$ On Ameil and his description of the illumination of the corpse see, Dykmans 1985, 219-223.
} 
as if he left the pope's body and its symbolic apparatus literally in the dark. ${ }^{57}$ Thus while de Conzié emphasized the destruction of the papal seals that freed for a time the institution from its human mold - and gave prominence to institutional continuity in the camerlengo's and cardinals' actions, Ameil silenced institutional continuity preferring to illuminate the man that had not yet separated from the institution.

By the late fourteenth century, the Christian public had been educated in Eucharistic devotion. In addition to the regular experience of witnessing the Elevation of the Host during mass, the late medieval faithful participated in Eucharistic processions during the newly founded feast. ${ }^{58}$ The feast, accompanied by a procession, was of course celebrated in Avignon where it had its origin. ${ }^{59}$ Familiar with the ceremony, François De Conzié and Pierre Ameil recorded the feast's liturgy in their ceremonials, and discussed its timing and octave, citing bulls and regulations emanating from both John XXII (who granted the feast an octave) and Clement VI who established procedures to follow when the feast encroached on other celebrations. ${ }^{60}$ De Conzié adds some information on the celebrations of the feast while Benedict XIII was in Perpignan for his council, as Ameil discusses cases when the feast displaced others like the celebration of the feast of St. Barnabe in 1382. ${ }^{61}$

Pierre Ameil subtly built up the bond that united the living pope to the Eucharist. ${ }^{62}$ And his conviction appears in unconventional ways. Ameil's discussion of the Feast of Corpus Christi's liturgy leads him to some unprompted remarks that underscore what I would call his understanding of the pope's organic position of authority as founded on his rapport with the Eucharist. Retelling the 1392 Roman festivities he recalls that Pope Boniface IX had been ill with kidney stones (quia passus calculus) and regardless of the pope's absence and the rules of the roman court, the cardinals on the day of Corpus Christi had wanted to hear high mass and the sermon in the Great Chapel. Come Migliorati, Cardinal of Bologna (the future Innocent VII) had eventually celebrated the mass. Retelling the event, Ameil cannot refrain himself from adding, "cardinals should never gather without licence to do so from the pope, neither for councils nor masses ... you must beware of breaching custom that would threaten the status or honor of the pontiff". ${ }^{63}$ The timing of Ameil's remarks during his discussion of the feast is remarkable. He was telling his readers that cardinals should not meet without papal approval and by having done so during the Feast of Corpus Christi they had betrayed Roman customs and the honor due to the status of the pope. Ameil was admonishing cardinals not to challenge the status and honor due to the Roman pontiff. His remarks imply first of all that indeed his experience of the Schism directed his narrative against cardinals but, more importantly, that he considered the pope's relation to the Corpus Christi essential in defining his authority. And what was valid for a living pope was valid for a dead one.

The pope held a special rapport with the host during the celebration of the Feast of Corpus Christi. Quoting Innocent III, Paravicini Bagliani emphasizes the elevated positioning of the

\footnotetext{
${ }^{57}$ Dykmans 1983, 262-270.

${ }^{58}$ For a detailed history of the feast and its liturgy see Rubin 1991, 164-212; for the feast's processions see, 243-271.

${ }^{59}$ See Rubin 1991, 181-183, where she discusses this integration; and Izbicki 2015, 230.

${ }^{60}$ For de Conzié see Dykmans 1983, vol. 1, 254-261; for Ameil see Dykmans 1985, 188-190.

${ }^{61}$ Dykmans 1983, vol. 1, 239; and 1985, 189.

${ }^{62}$ See his description of the feast in his ordo; Dykmans 1985, 188-189.

${ }^{63}$ Dykmans 1985, 190.
} 
pope during communion, "he in fact breaks [the bread of] the host at the altar, but communicates on the throne [in cattedra]; because Christ broke [the bread of] the host at Emmaus before two disciples, but ate at Jerusalem before eleven apostles". ${ }^{64}$ It can be inferred that by the late fourteenth-century the papal court and its public had been educated in certain visual clues surrounding the pope and the Eucharist. Lights shone on both. For Ameil, the foundation of papal authority rested on this symbiosis between pope and Christ and as such during his script of the pope's funeral he resisted separating what he viewed as one. The pope was bound to Christ. Cardinals were not. Ameil's views may not have been isolated. Many found extraordinary virtues in the body of the pope. Thomas Petra, a witness of the 1378 papal election describes the effervescence in Rome at the death of Pope Gregory. Crowds flocked to Rome to offer their devotion during the novena (and remember that this death in Rome was the first in many decades) but also because miracles were occurring on the body of the pope. $^{65}$

\section{Papal objectification}

Up to this point I have attempted to demonstrate how Ameil constructed the pope's body, as at once physical and institutional, formed by a unique Christological bond. As seen previously, Pierre Ameil was first in describing precisely the composition and use of balms in the preparation of the pope's body. The use of myrrh, and incense added sacramental quality and positioned his body outside human norms as he presented the pope's body as the anointed Corpus Christi. Visual clues also could lead observers of papal funerals to the flamboyant performances of the mass and celebrations of the Feast of Corpus Christi. Ameil also ignored in his liturgy the moment that separated the man-pope from his office when he silenced the destruction of the papal seals. I would like additionally to suggest that visually the embalmed papal corpse took on a wax-like quality that transfigured and sublimated the human into a highly symbolic object: the physical/objectified personification of the Church. It would be tempting to suggest that the pope's face, may actually have also been covered with a wax sheen--and made-up according to contemporary mores. The faces of noble men and women were made-up to preserve the illusion of life; it is highly possible that papal embalmers used similar methods. ${ }^{66}$ These would not have been recorded by Ameil because they were not liturgical, but nevertheless part of an embalmer's panoply of skills, and when done with talent, an advertisement for the quality of his work.

The association between wax and the human body has a long, uncanny history, going back centuries, well before Madame Tussauds' museum. Wax is found in votive offerings, and in funerary rites. ${ }^{67}$ During the Middle Ages the corpses of the nobility were wrapped in translucent waxed cloth (tela cerata) while the exposed faced was covered with a thin layer of painted wax. ${ }^{68}$ As Julius von Schlosser highlighted when discussing wax portraiture, "What stands at the forefront of the development is the portrait of the dead person, in its function of preserving the individual intact beyond the point of physical death; the magic of the portrait

\footnotetext{
${ }^{64}$ Paravicini Bagliani 2000, 66-67.

${ }^{65}$ Seidlmayer 1940, 261.

${ }^{66}$ See Olariu 2014.

${ }^{67}$ See Panzanelli, von Schlosser 2008, 184. See also Gill 2001; Holladay 2003; Eade 2013; Deckers 2013.

${ }^{68}$ Charuty 1992, 46-60. Other examples are found in Pollini 1994, 43; Morgan 2016, 170-172.
} 
works...through the closest possible resemblance to life". ${ }^{69}$ The long history of setting wax effigies in place of dead bodies may be something that did not escape the papacy and papal ceremonials' authors. ${ }^{70}$ What Roberta Panzanelli calls "the incestuous bond between wax and death" may have worked to the advantage of late medieval popes whose liturgists felt threatened, even symbolically, by the growing powers of the College of Cardinals. ${ }^{71}$

Ernst Kantorowicz was first in drawing attention to the presence of effigies during late medieval kings' funerals. Kantorowicz cites the effigy used for Edward II's funeral in 1327 as earliest evidence. Made of wood or leather in general, and sometimes wax, the effigies resembled the individual, dressed in coronation garments. Effigies displayed the insignia of sovereignty with crown, and artificial hands that held orb and scepter: "Enclosed in the coffin of lead which itself was encased in a casket of wood, there rested the corpse of the king, his mortal and normally visible - through now invisible - body natural; whereas his normally invisible body politic was on this occasion visibly displayed by the effigy in its pompous regalia; a persona ficta - the effigy - impersonating a persona ficta - the dignitas". ${ }^{72}$ To return to the topic of ecclesiastical funerals, Agostino Paravicini Bagliani, building from the discussion pertaining to the king's two bodies, tried to reconcile secular with religious conceptions. ${ }^{73}$ For Paravicini Bagliani, "the novena rendered possible the visibility of two bodies: The corpse of the dead pope, publicly exhibited his visage uncover, and the corpus ecclesie, represented in a similarly visible ways of the College of Cardinals". ${ }^{74}$ I would like to suggest that Ameil's funerary liturgy attempted to construct a symbolic reading close to that of monarchical writers, by replacing monarchical effigies with the actual body of the pope, embalmed and objectified, as a symbol of institutional continuity. ${ }^{75}$ Ameil brought the objectification of the pope's dead body even closer to the monarchical model when he itemized the clothing of the papal corpse for its exposition. Ameil instructs to dress him, "[1]ike if he was going to officiate, and they put on his head the white biretta with the white mitre without pearls or gold". ${ }^{76}$ Here Ameil insists on the color that the pope "living image of Christ on earth" wore most often. ${ }^{77}$ Remaining pure as it was uncorrupted the embalmed body of the pope escaped death.

\footnotetext{
${ }^{69}$ Panzanelli, von Schlosser 2008, 184.

${ }^{70}$ See Panzanelli, von Schlosser 2008, for an updated historiography.

${ }^{71}$ Panzanelli, von Schlosser 2008, 12.

${ }^{72}$ Kantorowicz 1957, 421. It is of note that in her latest review of the work Elizabeth Brown notes "Appealing as Kantorowicz's and Giesey's ideas have proved to be, it is not clear to me how relevant their theories are to the thinking of those who displayed and observed royal effigies and royal tombs from the XIV ${ }^{\text {th }}$ century onwards." She goes on offering counter evidence that both Kantorowicz and Giesey chose to ignore emerging from authors who attested that "the image's [effigy] proper function was to remind observers of the king who had died and lead them to revere his memory." Thus, some contemporary authors were upset that the effigy and not the king's body received the honors as, at the same time, effigies became a funerary fashion employed by many people who did not hold royal dignitas; Brown 2014, 119, $122,132$.

${ }^{73}$ Paravicini Bagliani 2000, xvi-xvii. This is also the theme of Rollo-Koster 2008.

${ }^{74}$ Paravicini Bagliani 2013, 224.

${ }^{75}$ See Rollo-Koster 2008, especially Chapter 1 and 2, 1-107.

${ }^{76}$ Dykmans 1985, 219.

${ }^{77}$ Paravicini Bagliani 2000, 89.
} 


\section{Conclusion}

Agostino Paravicini Bagliani in his discussion of the pope's body states, "[ $t$ ]he novena [the nine days of funerary observances] rendered possible the visibility of two bodies: The corpse of the dead pope, publicly exhibited with his visage uncovered [so onlookers witnessed death], and the corpus ecclesie, represented in a similarly visible way by the living College of Cardinals". ${ }^{78}$ But this construction needs to be reframed. After the initiation of the Schism, and anxious about what had recently occurred when cardinals grew impatient with the pope's authority, Pierre Ameil altered the symbolic presentation of the papal body during obsequies. In his ordo, Ameil attempted to construct a reading of the papal death and funeral that approximated similar ceremonies associated with secular monarchies. He replaced monarchical effigies with the actual body of the pope, embalmed and objectified, as a symbol of institutional continuity.

Interestingly, the monarchical model of tomb effigies, something distinct from the funeral procession effigies, eventually reached the Roman and Avignonese curia. Even though ecclesiastical tombs eventually became adorned in the same style as monarchical effigies, as the title of Julian Gardner's The Tomb and The Tiara indicates, the effigies never found their places in the papal funerary ritual. ${ }^{79}$ A papal effigy was not required since the pope, embalmed and displayed, was the effigy. The embalmed papal corpse was for Ameil the body natural and politic of the Church, at once physical and object, human and institution. Thus, the pope's body was naturally two, natural and politic. But unlike the body of a king, the pope's body was not separated at death; it remained one.

\section{Joëlle Rollo-Koster}

The University of Rhode Island

Joellekoster@uri.edu

\footnotetext{
${ }^{78}$ Paravicini Bagliani 2013, 224.

${ }^{79}$ Gardner 1992.
} 


\section{BIBLIOGRAPHY}

Albert J.-P. 1990: Odeurs de sainteté. La mythologie chrétienne des aromates, Paris.

Andrieu M. 1931-1961: Les ordines romani du haut moyen âge, Louvain. 5 vols.

Andrieu M. 1938-1941: Le pontifical romain au moyen âge. Città del Vaticano. 4 vols.

Ariès P. 1985: Images of Man and Death (Cambridge, Mass.).

Belting H. 1990: Bild und Kult: eine Geschichte des Bildes vor dem Zeitalter der Kunst, Munich.Benoit J.L. 2012: "Autour de l'odeur de sainteté, les parfums dans le monde chrétien", IRIS, 55-89, from halshs-00918676.

Biget J.L. 2004: "Introduction", in H. Millet (ed.), Le Midi et le Grand Schisme d'Occident, Toulouse, 910.

Blaauw S. de 1994, Cultus et decor: liturgia e architettura nella Roma tardo antica e medievale: basilica Salvatoris, Sanctae Mariae, Sancti Petri, Città del Vaticano.

Brown E.A.R. 2014: "The French Royal Funeral Ceremony and the King's Two Bodies: Ernst H. Kantorowicz, Ralph E. Giesey and the Construction of a Paradigm", in Micrologus 22, 105-137.

Charuty G. 1992: "Le vœu de vivre: Corps morcelés, corps sans âme dans les pèlerinages portugais", Terrain: Anthropologie et sciences humaines 18, 46-60.

Chiffoleau J. 1980: La comptabilité de l'au-delà: les hommes, la mort et la religion dans la région d'Avignon à la fin du Moyen Age (vers 1320-vers 1480), Rome.

Clarke P.D. 2009: "Between Avignon and Rome: Minor Penitentiaries at the Papal Curia in the Thirteenth and Fourteenth Centuries", RSCI 63, 455-510.

Classen C. 1998: The Colour of Angels: Cosmology, Gender, and the Aesthetic Imagination, London, UK.

Classen C., Howes D., Synnott A. 2002: Aroma: A Cultural History of Smell, London, UK.

Deckers R. 2013: "La Scandalosa in Naples: A Veristic Waxwork as Memento Mori and Ethical Challenge", Oxford Art Journal 36, 75-91.

Denery D.G. 2005: Seeing and Being Seen in the Later Medieval World: Optics, Theology, and Religious Life, New York.

Dinzelbacher P. 1990: "Die Realpräsenz der Heiligen in ihren Reliquiaren und Gräbern nach mittelalterlichen Quellen”, in P. Dinzelbacher (ed.), Heili- genverehrung in Geschichte und Gegenwart, Ostfildern, 115-174.

Dykmans M. 1981: Le cérémonial papal de la fin du moyen âge à la renaissance: Tome II. De Rome en Avignon ou le cérémonial de Jacques Stefaneschi, Bruxelles.

Dykmans M. 1983: Le cérémonial papal de la fin du moyen âge à la renaissance: Les textes avignonnais jusqu'à la fin du grand schisme d'occident, Bruxelles. 2 vols.

Dykmans M. 1985: Le cérémonial papal de la fin du moyen âge à la renaissance: Le retour à Rome ou le ceremonial du patriarche Pierre Ameil, Bruxelles.

Eade J. 2013: "The Theatre of Death", Oxford Art Journal 36, 109-125.

Gardner J. 1992: The Tomb and the Tiara: Curial Tomb Sculpture in Rome and Avignon in the Later Middle Ages, Oxford.

Gill M.J. 2001: "Death and the Cardinal: The Two Bodies of Guillaume d'Estouteville", RenQ 54, 347 388.

Göller E. 1907: Die päpstliche Ponitentiarie von ihrem Ursprung bis zu ihrer Umgestaltung unter Pius V, Rome.

Harvey S. 2006: Scenting Salvation: Ancient Christianity and the Olfactory Imagination, Berkeley, CA.

Holladay J. 2003: “Tombs and Memory: Some Recent Books", Speculum 78, 440-450.

Izbicki T.M. 2015: The Eucharist in Medieval Canon Law, Cambridge, UK.

Jørgense D. 2013: "The Medieval Sense of Smell, Stench, and Sanitation”, in U. Krampl (ed.), Les cinq sens de la ville du Moyen Âge à nos jours, Tours, 301-313.

Kantorowicz E.H. 1957: The King's Two Bodies: A Study in Mediaeval Political Theology, Princeton.

Kessler H.L. 2004: Seeing Medieval Art, Peterborough, Ont.

La Grande chirurgie de maistre Guy de Chauliac...traduite nouvellement en François...par Maistre Simon Mingelousaulx... première édition [suivi de l'Antidotaire]: 1672, Bordeaux.

Le Guérer A. 1993: Scent: The Mysterious and Essential Powers of Smell, London.

Mabillon J. 1724: Museum Italicum: Seu Collectio Veterum Scriptorum Ex Bibliothecis Italicis, Paris. 2 vols. 
Marchal G.P., Rivière V. 1995: "Jalons pour une histoire de l'iconoclasme au moyen age", AnnHistScSoc 50, 1135-1156.

Morgan A. 2016: "Absent Material: Waxed, Wooden, and Ivory Writing Tablets in the Medieval and Modern Periods", in R.G. Sullivan, M. Pagès (eds.), Imagining the Self, Constructing the Past: Selected Proceedings from the 36th Annual Medieval and Renaissance Forum, Newcastle upon Tyne.

Olariu D. 2014: La genèse de la représentation ressemblante de l'homme: Reconsidérations du portrait à partir du XIIIe siècle, Bern.

Palazzo E. 1998: A History of Liturgical Books: From the Beginning to the Thirteenth Century, Collegeville.

Panzanelli R., Schlosser J. von 2008: Ephemeral Bodies: Wax Sculpture and the Human Figure, Los Angeles.

Paravicini Bagliani A. 2000: The Pope's Body, Chicago.

Paravicini Bagliani A. 2013: Morte e elezione del papa: norme, riti e conflitti: il Medioevo, Roma.

Paravicini Bagliani A. 2014: "Le corps du pape, vingt ans après", Micrologus 22, 13-25.

Pollini N. 1994: La mort du prince: rituels funéraires de la Maison de Savoie (1343-1451), Lausanne.

Reinarz J. 2014: Past Scents: Historical Perspectives on Smell, Champaign, ILL.

Roch M. 2009: L'intelligence d'un sens. Odeurs miraculeuses et odorat dans l'Occident du haut Moyen Âge (Ve-VIIIe siècles), Turnhout.

Rollo-Koster J. 2008: Raiding Saint Peter: Empty Sees, Violence, and the Initiation of the Great Western Schism (1378), Leiden.

Rollo-Koster J. 2009: "Civil Violence and the Initiation of the Schism", in J. Rollo-Koster, T. Izbicki (eds.), A Companion to the Great Western Schism (1378-1417), Leiden, 9-66.

Rollo-Koster J. 2015: Avignon and its Papacy (13091417): Popes, Institutions, and Society, Lanham, MD.
Rollo-Koster J. 2016: "Death of Clergymen: Popes and Cardinals' Death Rituals”, in J. Rollo-Koster (ed.), Death in Medieval Europe: Death Scripted and Death Choreographed, London, 164-185.

Rollo-Koster J., Izbicki T. (eds.) 2009: A Companion to the Great Western Schism (1378-1417), Leiden.

Rubin M. 1991: Corpus Christi: The Eucharist in Late Medieval Culture, Cambridge, UK.

Sand A. 2014: Vision, Devotion, and Self-Representation in Late Medieval Art, Cambridge UK.

Schimmelpfennig B. 1973: Die Zeremonienbücher der römischen Kurie im Mittelalter, Tubingen.

Schoenig S.A. 2016: Bonds of Wool: The Pallium and Papal Power in the Middle Ages, Washington.

Scribner R.W. 1990: "Das Visuelle in der Volksfrömmigkeit", in R.W. Scribner (ed.), Bilder und Bildersturm im Spätmittelalter und under frühen Neuzeit, Wiesbaden, 9-20.

Seidlmayer M. 1940: Die Anfänge des grossen abendländischen Schismas: Studien zur Kirchenpolitik insbesondere der Spanischen Staaten, Münster i.W.

Thun $\varnothing$ E. 2002: Image and Relic: Mediating the Sacred in Early Medieval Rome, Rome.

Truitt E.R. 2009: "The Virtues of Balm in Late Medieval Literature", Early Science and Medicine 14, 711736.

Walter P. 2013: "De l'image à l'imaginaire medieval", Medievalista (2013), from http://www2.fcsh.unl.pt/$\mathrm{iem} /$ medievalista/MEDIEVALISTA13/walter1303.ht $\mathrm{ml}$.

Wavrin J., Hardy E.L. C.P., Hardy W.: 1887, A Collection of the Chronicles and Ancient Histories of Great Britain, Now Called England, London.

Weiß S. 2009: "Luxury and Extravagance at the Papal Court in Avignon and the Outbreak of the Great Western Schism", in J. Rollo-Koster, T. Izbicki (eds.), A Companion to the Great Western Schism (1378-1417), Leiden, Boston, 67-87.

Woolgar C.M. 2006: The Senses in Late Medieval England, New Haven, Conn. 